\title{
Antioxidant Activity and Cytotoxicity Against WiDR Cell and Vero Cell of The Karamunting (Rhonomyrtus tomentosa L.) Leaves Ethanol Extract.
}

\author{
Marwati, Andi Anggriani, Asril Burhan*, Akbar Awaluddin, Syamsu Nur, Rizky \\ Dharmayanti, Ega Lilingan, Melkisedek D. Tiboyong.
}

Sekolah Tinggi Ilmu Farmasi Makassar, Sulawesi Selatan, Indonesia.

\author{
Submitted 31 March 2020; Revised 1 April 2021; Accepted 12 July 2021; Published 29 October 2021 \\ *Corresponding author: asrilburhan@gmail.com
}

\begin{abstract}
Karamunting (Rhodomyrtus tomentosa L.), a plant used as a traditional medicine, is widely distributed throughout Indonesia. Karamuting has the potential as an antioxidant and anticancer agents because of its phenolic and flavonoid components. This study aimed to determine total phenolic level, antioxidant activity and cytotoxic of karamunting leaves extract. The simplisia of karamunting leaves were extracted by maceration method using $96 \%$ ethanol, tested for its antioxidant activity using DPPH and its citotoxic by MTT method (3- (4,5-dimethyltiazol-2-il) -2,5-diphenyl tetrazolium bromide) on WiDr cells and Vero cells. The results of this study showed that the yield of karamunting extract were $15.635 \%$ with a total phenolic level of $0.76 \%$, antioxidant activity ( $\mathrm{IC}_{50}$ values) of $15,330 \mu \mathrm{g} / \mathrm{mL}$ and cytotoxicity (ICs0 values) of $205.7069 \mu \mathrm{g} / \mathrm{mL}$ for WiDr cells and $44.87703 \mu \mathrm{g} / \mathrm{mL}$ for Vero cells. Ethanol extract of karamunting leaves possessed a very strong antioxidant activity while it showed a weak cytotoxic effect on WiDr cells and toxic effect on Vero cells.
\end{abstract}

Keywords: Antioxidant, Anticancer, Karamunting

\section{Uji Aktivitas Antioksidan Ekstrak Etanol Daun Karamunting (Rhonomyrtus tomentosa L.) dan Sitotoksik Terhadap Sel WiDr dan Sel Vero.}

\begin{abstract}
Abstrak
Karamunting (Rhodomyrtus tomentosa L.) merupakan salah satu tanaman yang digunakan sebagai obat tradisional yang banyak tersebar diseluruh Indonesia, tanaman ini mempunyai potensi sebagai antioksidan dan antikanker dengan adanya kandungan senyawa fenolik dan flavanoid. Penelitian ini bertujuan untuk melihat total fenolik, aktivitas antioksidan dan sitotoksik dari ekstrak daun karamunting. Simplisia daun karamunting diekstraksi dengan metode maserasi menggunakan etanol $96 \%$, pengujian aktivitas antioksidan menggunakan DPPH serta diuji toksisitasnya dengan metode MTT (3-(4,5- dimetiltiazol-2-il)-2,5-difenil tetrazolium bromida) terhadap sel WiDr dan sel vero. Hasil dari penelitian ini mendapatkan rendemen $15,635 \%$,serta total fenolik total $0,76 \%$, Perolehan aktivitas antioksidan nilai IC $\mathrm{I}_{50}$ ekstrak etanol daun karamunting sebesar 15,330 $\mu \mathrm{g} / \mathrm{mL}$ dan Perolehan aktivitas sitotoksik dengan nilai IC so $_{0}$ sebesar 205,7069 $\mu \mathrm{g} / \mathrm{mL}$ terhadap sel WiDr dan 44,87703 $\mu \mathrm{g} / \mathrm{mL}$ pada sel vero. Berdasarkan hasil tersebut, aktivitas antioksidan ekstrak etanol daun karamunting masuk dalam kategori sangat kuat sedangkan untuk aktivitas sitotoksik terhadap sel WiDr tergolong lemah dan terhadap sel vero termasuk kategori toksik.
\end{abstract}

Kata Kunci: Antioksidan, Antikanker, Karamunting. 


\section{Pendahuluan}

Tanaman karamunting (Rhodomyrtus tomentosa L.) salah satu tanaman yang telah dikenal oleh masyarakat dan telah digunakan sebagai obat tradisional di beberapa daerah di Indonesia dengan cara merebus daunnya. Secara empiris daun Karamunting digunakan untuk mengobati diare, disentri, perdarahan, abses maupun sebagai antiseptik. ${ }^{1}$

Pemanfaatan tumbuhan sebagai obat tradisional tidak lepas dari adanya metabolit sekunder yang terkandung dalam suatu tanaman, salah satu golongan senyawa yang yang sering dimanfaatkan ialah fenolik. Golongan senyawa fenolik terdapat sangat luas di alam dan mempunyai variasi struktur dan mudah ditemukan di semua tanaman, baik pada daun, bunga maupun buah Salah satu tanaman Indonesia yang mengandung senyawa fenolik ialah karamunting. ${ }^{1}$

Berdasarkan penelusuran beberapa literatur, buah dan daun karamunting mengandung senyawa flavonoid, saponin, kuinon, tanin, dan steroid. ${ }^{2}$ Batang dan rantingnya mengandung senyawa flavonoid dan triterpenoid ${ }^{3}$. Sinata dan Arifin (2017), menjelaskan bahwa ektrak etanol daun karamunting dapat menurunkan kadar glukosa darah. ${ }^{4}$ Menurut Lavanya dkk., (2012), ekstrak daun aseton karamunting memiliki aktivitas antioksidan yang besar. ${ }^{5}$ Mordmuang dan Voravuthikunchai (2015) , menjelaskan bahwa ekstrak etanol daun karamunting memiliki aktivitas antibakteri dan antiinflamasi. ${ }^{6}$ Pada penelitian Yun (2014), dilakukan uji aktivitas antikanker pada sel P-388 yang bersifat sangat toksik dengan memiliki hasil tertinggi dengan nilai $\mathrm{IC}_{50}$ 5,6 ppm terdapat pada fraksi N-Heksan, sedangkan nilai $\mathrm{IC}_{50}$ isolate $\mathrm{n}$-heksan, fraksi etil asetat yaitu 13,12 ppm dan 14,93 ppm. ${ }^{7}$

Penelitian ini bertujuan untuk melihat total fenolik serta aktivitas antioksidan dan sitotoksik ekstrak daun karamunting, penelitian ini dilaksanakan di laboratorium Sekolah Tinggi Ilmu Farmasi Makassar dan RSP UNHAS.

\section{Metode}

2.1. Alat
Spektrofotometer UV-Vis (Shimadzu), tabung reaksi (pyrex $\left.{ }^{\circledR}\right)$, batang pengaduk,

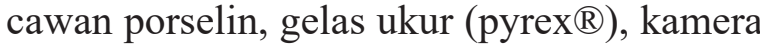
(canon), erlemenyer, spatel, lampu spiritus, neraca analitik (mettle Toledo), penjepit tabung, rak tabung, inkubator (Nesco $\left.{ }^{\circledR}\right)$, mikroskop inverted (Olympus), mikro pipet (bio rad), microplate 96 sumuran / well plate 96 (iwaki), tabung eppendorf (Nesco®), ELISA reader (thermo fischer scientific), vortex mixer (heidolph), conical tube (coming), tip mikropipet (Scilogex), botol duran, botol kultur/tissue culture flask (Nuncione) dan toples kaca.

\subsection{Bahan}

Asam galat, aquadest, etanol p.a, $\mathrm{Na}_{2} \mathrm{CO}_{3} 1 \%$, dan pereaksi Folin-Ciocalteu, etanol 70\%, n-heksan, etil asetat, aquadest, kuersetin, 2,2 diphenyl-1-picrylhydrazyl (DPPH), asam klorida, besi III nitrat $\left(\mathrm{FeCl}_{3}\right)$, Acidum sulfuricum $\quad\left(\mathrm{H}_{2} \mathrm{SO}_{4}, \quad\right.$ Sigma $)$, media RPMI ( Roswell park Memortal Institute) (gibco), media DMEM (Dubecco's modified eagle medium) (gibco), DMSO (Dimethyl Sulfoxide) (Merck), MTT (3-(4,5dimetiltiazol-2-il-2-5-difenil tetrazolium bromide), $\mathrm{NaHCO}_{3}$, FBS (Fetal Bovine Serum) (gibco), kultur sel kanker WiDr, kultur sel vero, tripsin EDTA 0,25\% (gibco).

\subsection{Prosedur}

2.3.1. Pembuatan Ekstrak etanol daun Karamunting.

Tanaman diperoleh dari Desa Kanuruan Salu sopai, Kabupaten Toraja Utara, Provinsi Sulawesi Selatan, dan determinasi dilakukan di Fakultas Ilmu Pengetahuan Alam Laboratorium biologi negeri Makassar (UNM). Simplisia Daun Karamunting diekstrasi dengan etanol 96\% dengan metode maserasi. Simplisia diekstraksi dengan pelarut etanol 96\% dimana serbuk simplisia dan pelarut dimasukan dalam wadah maserasi. Kemudian Didiamkan selama 3-5 hari dalam suhu kamar dan terlindung cahaya sambil sesekali di aduk.

\subsubsection{Penetapan kadar total Fenolik Ekstrak etanol daun Karamunting di}


larutkan dengan etanol p.a, ditambahkan dengan pereaksi Folin-Ciocalteu, $\mathrm{Na}_{2} \mathrm{CO}_{3}$ $1 \%$ dan ditambahkan air suling sampai tanda batas, dikocok sampai homogen. Campuran didiamkan selama 30 menit kemudian absorbansi diukur menggunakan spektrofotometer UV-Vis pada panjang gelombang maksimum. Pengukuran dilakukan sebanyak tiga kali. Fenol total dihitung dengan menggunakan persamaan regresi linear dari kurva kalibrasi asam galat.

Untuk kadar fenolik dapat menggunakan rumus :

$$
\mathrm{TPC}=\frac{x \times \frac{1}{1000} \times \mathrm{V} \times \mathrm{Fp}}{\text { bobot sampel }} \times 100 \%
$$

Keterangan :

TPC: Total Phenolic Content $(\% \mathrm{~b} / \mathrm{b})$

$\mathrm{X}$ : Kesetaraan asam galat $(\mu \mathrm{g} / \mathrm{ml})$

$\mathrm{V}$ : Volume total ekstrak (ml)

Fp: Faktor pengenceran (ml)

Bobot sampel: Berat sampel yang ditimbang (mg)

\subsubsection{Pengukuran Aktivitas antioksidan dengan DPPH}

Pengujian dilakukan dengan cara memipipet larutan stok $100 \mathrm{bpj}$ dengan volume $10 \mu 1,20 \mu 1,30 \mu 1,40 \mu 1,50 \mu 1$ ditambahkan 60 $\mu 1$ larutan DPPH dan dicukupkan volumenya hingga $200 \mu \mathrm{l}$ dengan etanol p.a ke dalam well plate 96. Kemudian dihomogenkan dan di inkubasi selama 30 menit pada suhu ruangan, setelah diinkubasi di ukur serapan larutan sampel dengan menggunakan Elisa reader pada panjang gelombang $515 \mathrm{~nm}$, pengujian dilakukan sebanyak 3 replikasi. Untuk pengukuran aktivitas pembanding (kuersetin) Larutan stok kuersetin $10 \mathrm{bpj}$ di pipet masing-masing $10 \mu \mathrm{l}, 20 \mu \mathrm{l}, \mu \mathrm{g} /$ $\mathrm{ml} 30 \mu \mathrm{g} / \mathrm{ml}, 40 \mu \mathrm{g} / \mathrm{ml}$ dan $50 \mu \mathrm{g} / \mathrm{ml}$,masingmasing ditambahkan $60 \mu \mathrm{l} \mathrm{DPPH}$, kemudian dicukupkan volumenya $200 \mu \mathrm{l}$ dengan etanol p.a, sehingga di peroleh konsentrasi, diinkubasi pada ruangan gelap selama 30 menit pada suhu kamar. Setelah itu diukur menggunakan Elisa reader dengan panjang gelombang $515 \mathrm{~nm}$ dan direplikasikan tiga kali. Perhitung \% aktivitas antioksidan dengan rumus :

Aktivitas antioksidan $=\frac{\text { Abs Blanko }- \text { Abs sampel }}{\text { Abs Blanko }} \times 100 \%$

2.3.4. Penentuan aktivitas sitotoksik ekstrak daun karamunting terhadap sel WIDr dan vero.

Sel yang telah dihitung kemudian didistribusikan pada sumuran sesuai jumlah ekstrak uji (30 sumuran) dan kontrol negatif (3 sumuran). Masing-masing sampel uji dan kontrol dibuat replikasi triplo, kemudian campuran diinkubasi dalam inkubator yang dialiri $\mathrm{CO}_{2}$ pada suhu $37^{\circ} \mathrm{C}$ selama 24 jam untuk sel beradaptasi dan menempel di sumuran sampai sel siap untuk diberi perlakuan.

Setelah akhir masa inkubasi, microplate yang berisi sel diambil dari inkubator kemudian dibuang media dengan cara microplate dibalikan diatas tempat buangan kemudian plate ditekan untuk meniriskan cairan. Larutan uji ekstrak daun afrika yang telah diencerkan dengan media pada 5 seri konsentrasi dimasukan dalam sumuran yang telah berisi sel WiDr/vero dimulai dari konsentrasi terkecil masingmasing sebanyak $100 \mu \mathrm{L}$, sedangkan pada sumuran kontrol negatif dimasukan media sesuai sel yang digunakan sebanyak $100 \mu \mathrm{L}$ kemudian microplate diinkubasi kembali dalam inkubator yang dialiri $\mathrm{CO} 2$ pada suhu $37^{\circ} \mathrm{C}$ selama 24 jam.

Setelah akhir masa inkubasi, media sel dibuang kembali dan reagen MTT konsentrasi $0,5 \mathrm{mg} / \mathrm{ml}$ disiapkan dengan car sebanyak 1 $\mathrm{mL}$ larutan MTT $5 \mathrm{mg} / \mathrm{ml}$ ditambahkan media hingga $10 \mathrm{~mL}$. Larutan MTT didistribusikan ke dalam sumuran ekstrak uji, kontrol negatif dan blanko masing-masing 100 $\mu \mathrm{L}$, microplate dibungkus aluminium foil dan dan didinkubasi kembali selama 4 jam dalam inkubator yang dialiri $\mathrm{CO}_{2}$ pada suhu $37^{\circ} \mathrm{C}$. Pada akhir inkubasi ditambahkan DMSO sebanyak $100 \mu \mathrm{L}$, didiamkan 10 menit kemudian seraoan ukur dengan ELISA reader pada panjang gelombang $595 \mathrm{~nm}$. Persen kematian sel dihitung dari data yang diperoleh. 
Nilai $\%$ kematian ditentukan menggunakan rumus :

$\%$ kematian $=$

Kontrol negatif-sampel X 100\%

\section{Hasil}

3.1. Hasil rendamen ekstrak karamuntunting Setelah melakukan ekstraksi daun karamunting dengan menggunakan pelarut etanol maka didapatkan rendamen seperti pada tabel 1 .

\subsection{Hasil pengukuran Fenolik total daun karamunting}

Hasil pengukuran fenolik total daun karamunting dapat dilihat pada tabel 2. Pada pengukuran senyawa fenolik total dibuat sebanyak tiga replikasi untuk keperluan akurasi data. Berdasarkan hasil penelitian ini diperoleh kadar fenolik total ekstrak etanol Daun Karamunting sebesar $0,76 \%$ EAG, yang artinya dalam setiap gram ekstrak etanol Daun Karamunting terdapat fenolik yang setara dengan $0.76 \%$ asam galat.

\subsection{Hasil pengukuran Antioksidan daun karamunting}

Pengujian aktivitas antioksidan pada penelitian ini menggunakan metode DPPH hasil pengujian aktivitas antioksidan dari masing-masing ekstrak dapat dilihat pada tabel 3 .

3.4. Hasil pengujian sitotoksik daun karamunting terhadap sel WiDr dan Hela

Dari pengujian sitotoksik daun karamunting didapatkan nilai $\mathrm{IC}_{50}$ seperti pada tabel 4 .

\section{Pembahasan}

Penetapan kadar fenolik total dilakukan dengan menggunakan reagen Folin-Ciocalteau. Reagen Folin Ciocalteau digunakan karena senyawa fenolik dapat bereaksi dengan Folin membentuk larutan berwarna yang dapat diukur absorbansinya. Prinsip dari metode folin ciocalteau adalah terbentuknya senyawa kompleks berwarna biru yang dapat diukur pada panjang gelombang $765 \mathrm{~nm}$. Pereaksi ini mengoksidasi fenolat (garam alkali) atau gugus fenolik-hidroksi mereduksi asam heteropoli (fosfomolibdat-fosfotungstat) yang terdapat dalam pereaksi Folin Ciocalteau menjadi suatu kompleks molibdenumtungsten. Senyawa fenolik bereaksi dengan reagen Folin Ciocalteau hanya dalam suasana basa agar terjadi disosiasi proton pada senyawa fenolik menjadi ion fenolat. Untuk membuat kondisi basa digunakan $\mathrm{Na}_{2} \mathrm{CO}_{3}$ $7,5 \%$. Gugus hidroksil pada senyawa fenolik bereaksi dengan reagen Folin Ciocalteau membentuk kompleks molibdenumtungsten berwarna biru yang dapat dideteksi dengan spektrofotometer. Semakin besar konsentrasi senyawa fenolik maka semakin banyak ion fenolat yang akan mereduksi asam heteropoli (fosfomolibdat-fosfotungstat) menjadi kompleks molibdenum-tungsten sehingga warna biru yang dihasilkan semakin pekat. Dari hasil yang didapatkan total fenolik yang terdapat pada ekstrak daun karamunting sebesar $0,76 \%$ EAG dimana semakin besar total fenolik didalam ekstrak maka semakin besar pula potensi sebagai antioksidan.

Berdasarkan hasil absorbansi pada tabel 3, setelah perhitungan $\mathrm{IC}_{50}$ maka diperoleh nilai $\left(\mathrm{IC}_{50}\right) \quad 15,331 \mu \mathrm{g} / \mathrm{mL}$. Menurut Aminah, (2016), suatu senyawa dinyatakan sebagai antiradikal bebas sangat kuat apabila nilai $\mathrm{IC}_{50}<10 \mu \mathrm{g} / \mathrm{mL}$, kuat apabila nilai $\mathrm{IC}_{50}$ antara $10-50 \mu \mathrm{g} / \mathrm{mL}$, sedang apabila nilai $\mathrm{IC}_{50}$ berkisar antara $50-100 \mu \mathrm{g} / \mathrm{mL}$, lemah apabila nilai $\mathrm{IC}_{50}$ berkisar antara $100-250 \mu \mathrm{g} / \mathrm{mL}$ dan tidak aktif apabila $\mathrm{IC}_{50}$ diatas $250 \mu \mathrm{g} / \mathrm{mL}^{8}$, dari pernyataan diatas menunjukkan bahwa ekstrak etanol daun karamunting tergolong dalam antioksidan dengan intensitas yang kuat $(<50 \mu \mathrm{g} / \mathrm{mL})$ karena diperoleh nilai $\mathrm{IC}_{50}$ sebesar $15,331 \mu \mathrm{g} / \mathrm{mL}$. Pada umumnya senyawa fenolik mempunyai sifat antioksidan

Tabel 1. Hasil perhitungan rendemen

\begin{tabular}{cccc}
\hline Sampel & Bobot simplisia & Berat ekstrak (g) & Rendemen (\%) \\
\hline Ekstrak Etanol & $200 \mathrm{~g}$ & $31,27 \mathrm{~g}$ & $15,635 \%$ \\
\hline
\end{tabular}


Tabel 2. Hasil pengukuran fenolik total ekstrak etanol daun karamunting

\begin{tabular}{ccccc}
\hline Ekstrak & Replikasi & Absorbansi & Fenolik Total (\%) & Rata-Rata Fenolik Total (\%) \\
\hline Etanol $70 \%$ & I & 0.588 & $0.78 \%$ & $0.76 \%$ \\
& II & 0.596 & $0.79 \%$ & \\
& III & 0.551 & $0.73 \%$ & \\
\hline
\end{tabular}

yang kuat oleh sebab itu ekstrak etanol daun karamunting mempunyai potensi sebagai antioksidan alami. Antiokidan erat kaitanya dengan antikanker dimana antioksidan mempunyai mekanisme kerja menangkap radikal bebas yang dapat menyebabkan penyakit kanker.

Berdasarkan hasil tabel 4 bahwa ketujuh konsentrasi ekstrak etanol daun karamunting memiliki nilai ICso sel WiDr 205,7069 $\mu \mathrm{g} /$ $\mathrm{mL}$, sedangkan nilai $\mathrm{IC}_{50}$ sel vero yaitu 44,87793 $\mu \mathrm{g} / \mathrm{mL}$. Menurut meiyanto (2008), menyebutkan suatu ekstrak dapat dinyatakan aktif, poten atau positif apabila memiliki nilai $\mathrm{IC}_{50}<20 \mathrm{ppm}$ (sangat toksik), 21-200 ppm (toksik), 201-500 ppm (toksik lemah), dan $>500$ ppm (tidak toksik). ${ }^{9}$

Dapat dilihat bahwa semakin kecil nilai $\mathrm{IC}_{50}$ yang dihasilkan suatu senyawa maka semakin besar aktivitas sitotoksiknya. Hal ini berarti ekstrak etanol daun karamunting memiliki efek sitotoksik bersifat toksik lemah terhadap sel WiDr, dan memiliki efek sitotoksik bersifat toksik terhadap sel vero.

Ekstrak etanol daun karamunting memiliki senyawa metabolit sekunder yang berperan sebagai antikanker yaitu Senyawa flavonoid, saponin dan tanin. Senyawa Flavanoid memiliki senyawa kuersetin yang secara signifikan mampu menghambat proliferasi sel dan menginduksi cell cycle arrest serta apoptosis pada sel kanker WiDr. ${ }^{10}$ Senyawa saponin dapat berpotensi sebagai antikanker dengan menghambat pembentukan Bcl-2 yang diekspresikan terlalu tinggi, menginduksi protein caspase-3 yang diekspresikan terlalu rendah, meningkatkan ekspresi p53, dan dapat pula memicu G1 cell cycle arrest. ${ }^{11}$ Golongan senyawa Tanin yang berguna sebagai antikanker seperti

Tabel 3. Hasil uji antioksidan ekstrak etanol daun karamunting

\begin{tabular}{|c|c|c|c|c|c|}
\hline $\begin{array}{l}\text { Konsentrasi } \\
\text { (bpj) }\end{array}$ & Replikasi & Absorbansi & $\begin{array}{c}\text { Rata-rata } \\
\text { penghambatan }\end{array}$ & $\%$ inhibisi & Nilai IC I0 $_{50}$ \\
\hline \multirow[t]{3}{*}{ Blanko } & 1 & 0,895 & 0,832 & & \multirow{18}{*}{$15,330 \mu \mathrm{g} / \mathrm{mL}$} \\
\hline & 2 & 0,801 & & & \\
\hline & 3 & 0,801 & & & \\
\hline \multirow[t]{3}{*}{5} & 1 & 0,513 & 0,595 & 28,434 & \\
\hline & 2 & 0,635 & & & \\
\hline & 3 & 0,639 & & & \\
\hline \multirow[t]{3}{*}{10} & 1 & 0,494 & 0,511 & 38,566 & \\
\hline & 2 & 0,513 & & & \\
\hline & 3 & 0,527 & & & \\
\hline \multirow[t]{3}{*}{15} & 1 & 0,400 & 0,411 & 50,620 & \\
\hline & 2 & 0,443 & & & \\
\hline & 3 & 0,390 & & & \\
\hline \multirow[t]{3}{*}{20} & 1 & 0,347 & 0,340 & 59,070 & \\
\hline & 2 & 0,338 & & & \\
\hline & 3 & 0,337 & & & \\
\hline \multirow[t]{3}{*}{25} & 1 & 0,245 & 0,250 & 69,883 & \\
\hline & 2 & 0,259 & & & \\
\hline & 3 & 0,248 & & & \\
\hline
\end{tabular}


Tabel 4. Hasil uji sitotoksik ekstrak etanol daun karamunting terhadap sel WiDr dan Hela

\begin{tabular}{ccccc}
\hline $\begin{array}{c}\text { Konsentrasi } \\
\text { (bpj) }\end{array}$ & Sel WiDr & Sel Vero & Sel WiDr & Sel Vero \\
\hline 7,81 & 3,295 & 18,7798 & & \\
15,63 & 10,954 & 27,328 & & \\
31,25 & 20,235 & 36,7059 & & \\
62,50 & 33,727 & 62,1559 & $205,7069 \mu \mathrm{g} / \mathrm{mL}$ & $44,8779 \mu \mathrm{g} / \mathrm{mL}$ \\
125 & 42,012 & 73,3457 & & \\
250 & 54,034 & 80,1284 & & \\
500 & 60,763 & 100,165 & & \\
\hline
\end{tabular}

mekanisme flavonoid yaitu pengaktifan jalur apoptosis sel kanker. Tanin mampu menghambat poliferasi kanker yang salah satunya dengan menginhibisis aktivitas protein kinase sehingga menghambat jalur transduksi sinyal dari membran ke inti sel. Tanin juga menghambat aktivitas reseptor tirosin kinase yang mengikat berperan dalam pertumbuhan keganasan sel kanker. Dan tannin berfungsi mengurangi resistensi tumor terhadap agen kemoterapi. ${ }^{9}$

\section{Simpulan}

Berdasarkan penelitian yang telah dilakukan, dapat disimpulkan bahwa ekstrak etanol daun karamunting (Rhodomyrtus tomentosa L.) mengandung total fenolik $0,76 \%$, nilai $\mathrm{IC}_{50}$ sebesar $15,330 \mu \mathrm{g} / \mathrm{mL}$ dan memiliki efek toksik lemah terhadap sel kanker WiDr dengan nilai $\mathrm{IC}_{50} 205,7069$ ppm dan toksik kuat terhadap sel vero dengan nilai $\mathrm{IC}_{50} 44,8779 \mu \mathrm{g} / \mathrm{mL}$.

\section{Daftar Pustaka}

1. Balitbang Kesehatan Kemenkes RI. Riset Sutomo., Arnida., Febri, H., Yuwono M. Kajian Farmakognostik Simplisia Daun Karamunting (Rhodomyrtus tomentosa) asal Pelaihari Kalimantan Selatan. Sains dan Terap Kim. 2010;4(1):38-50.

2. Putri, A.A., Mulkiya, K., Sadiyah ER. Pengaruh Perbedaan Pelarut Ekstra Terhadap Kadar Senyawa yang Berpotensi Memiliki Aktivitas Analgetik dari Ekstrak Daun dan Buah Karamunting (Rhodomyrtus Tomentosa (Aiton) Hassk.). Pros Penelit Spes. 2015;

3. Kusuma Iw, Ainiyati N, Suwinarti W.
Search for biological activities from an invasive shrub species rosemyrtle (Rhodomyrtus tomentosa). Nusant Biosci. 2016;8(1):55-9.

4. Sinata N, Arifin H. Uji Aktivitas Antidiabetes Fraksi dari Ekstrak Etanol Daun Karamunting (Rhodomyrtus Tomentosa (Ait.) Hassk.) Terhadap Mencit Diabetes. J Farm Galen. 2017;3(2):41-6.

5. Lavanya G, Voravuthikunchai SP, Towatana NH. Acetone Extract from Rhodomyrtus tomentosa: A Potent Natural Antioxidant. Bankova V, editor. Evidence-Based Complement Altern Med. 2012;2012:535479.

6. Mordmuang A, Voravuthikunchai SP. Rhodomyrtus tomentosa (Aiton) Hassk. leaf extract: An alternative approach for the treatment of staphylococcal bovine mastitis. Res Vet Sci. 2015 Oct;102:2426.

7. Yun, Yenny Febrian, Lilis Siti Aisyah, Cecep Chandra Alfrilindo AM. Aktitivitas Sitotoksik Metabolit Sekunder Daun Tumbuhan Keremunting (Rhodomyrtus tomentosa (Aiton) Hassk) Asal Belitung Terhadap Sel Leukimia P-388. In: Seminar Nasional Ilmu Pengetahuan dan Teknologi Universitas Jenderal Achmad Yani. 2014.

8. Aminah A, Maryam S, Baits M, Kalsum U. Perbandingan aktivitas antioksidan ekstrak etanol daun sirsak (annona muricata 1.) Berdasarkan tempat tumbuh dengan metode peredaman dpph. J Fitofarmaka Indones. 2016;3(1):146-50.

9. Meiyanto E, Susidarti RA, Handayani S, Rahmi F. Ekstrak Etanolik Biji Buah 
Pinang (Areca Cathecu L.) Mampu Menghambat Proliferasi dan Memacu Apoptosis Sel MCF-7. Maj Farm Indones. 2008;19(1):12-9.

10. Mardiyangsih A, Ismiyat N. Cytotoxic Activity Of Ethanolic Extract Of Persea americana Mill . Leaves On HeLa Cervical Cancer Cell. Tradit Med Journa.
2014;19:24-8.

11. Fitria M,ArmandariI, Septhea DB, Ikawati AHM, Meiyanto E. Effect of ethanolic extract of ciplukan herbs (Physalis angulata L. ) on cytotoxic and apoptosis induction in MCF-7 breast cancer cell lines. Bionatura. 2011;13(2):101-7. 